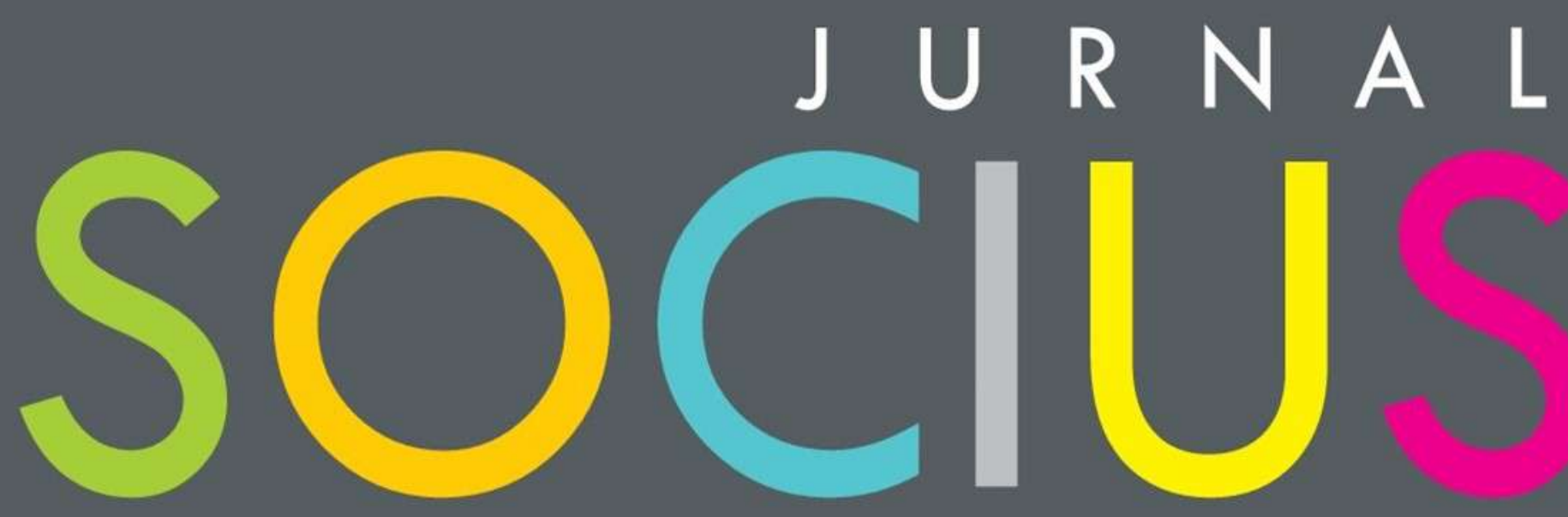

Journal of Sociology Research and Education

DITERBITKAN OLEH :

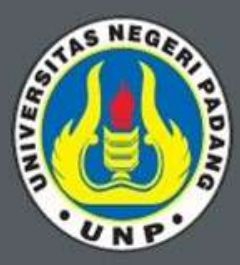

LABOR JURUSAN SOSIOLOGI FAKULTAS ILMU SOSIAL UNIVERSITAS NEGERI PADANG

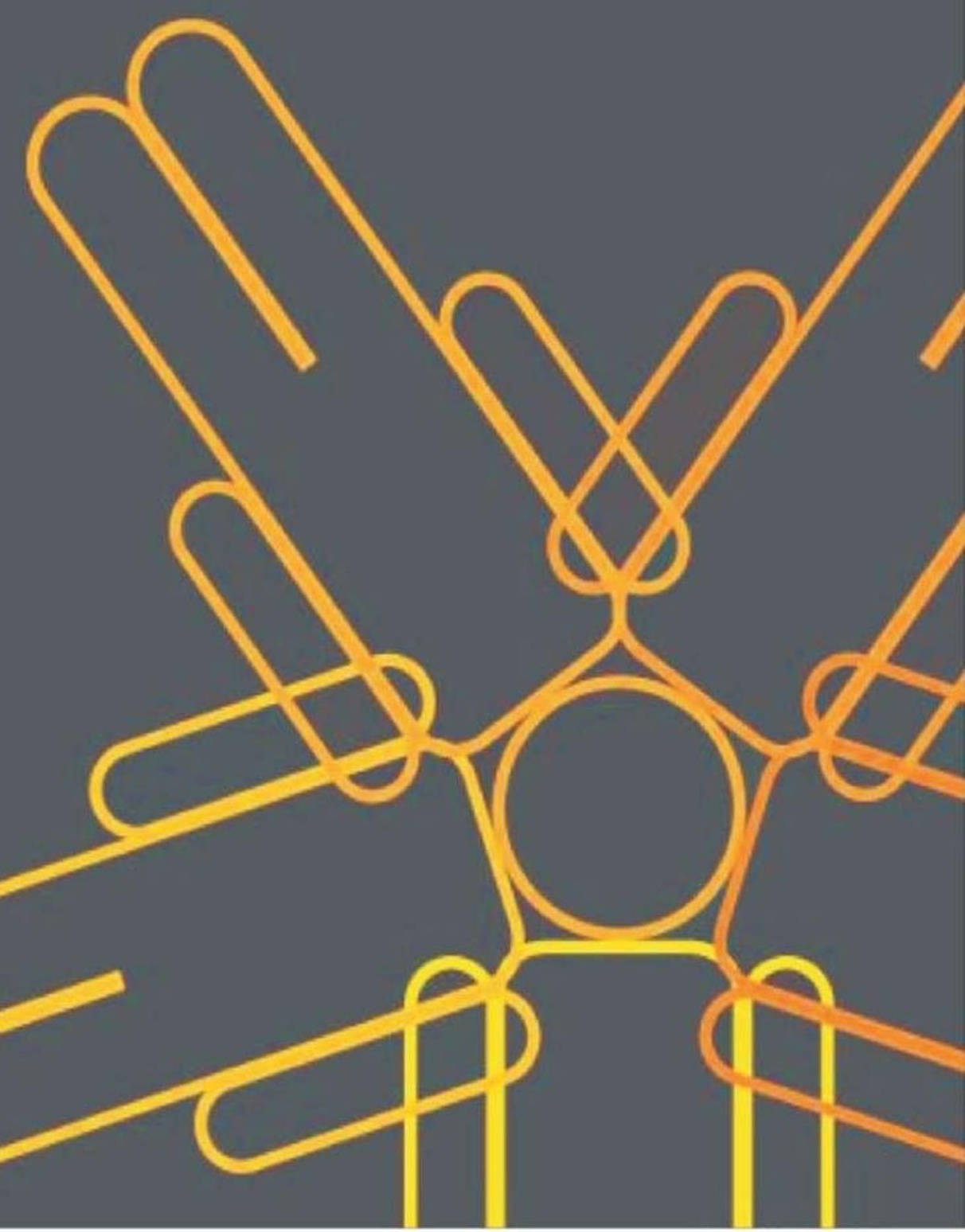




\section{SOCIUS}

Vol. 6, No.2, Th. 2019

ISSN : 2356-4180 (cetak)

2442-8663 (online)

\begin{tabular}{|c|c|}
\hline $\begin{array}{c}\text { REDAKSI } \\
\text { JURNAL SOCIUS }\end{array}$ & DAFTAR ISI \\
\hline $\begin{array}{c}\text { Editor in Chief : } \\
\text { Selinaswati } \\
\text { Managing Editor : } \\
\text { Erda Fitriani } \\
\text { Editorial Board: } \\
\text { Eka Vidya Putra } \\
\text { Desy Mardiah } \\
\text { Ike Sylvia } \\
\text { Erianjoni } \\
\text { Mohammad Isa Gautama } \\
\text { Reno Fernandes }\end{array}$ & $\begin{array}{c}\text { Mutia Kahana, Junaidi } \\
\text { Pengaruh Penerapan Model Konsiderasi Terhadap Pembentukan } \\
\text { Sikap Siswa dalam Pembelajaran Sosiologi di Kelas XI IPS SMA } \\
\text { Adabiah Padang } \\
\text { Halaman 62-69 } \\
\text { Reno Fernandes } \\
\text { Revolusi 4.0 } \\
\text { Halaman } 70-80\end{array}$ \\
\hline $\begin{array}{c}\text { Reviewer: } \\
\text { Rebecca Fanany } \\
\text { Elly Malihah } \\
\text { (Deakin Univerity, Australia) } \\
\text { (Universitas Pendidikan Indonesia, Indonesia) } \\
\text { Nur Hidayat Sardini } \\
\text { (Universitas Diponegoro, Indonesia) } \\
\text { Ubedilah Badrun } \\
\text { ( Universitas Negeri Jakarta, Indonesia) } \\
\text { Moh. Yasir Alimi } \\
\text { (Universitas Negeri Semarang, Indonesia) } \\
\text { Ferdinand Kerebungu } \\
\text { (Universitas Negeri Menado, Indonesia) } \\
\text { Jendrius } \\
\text { (Universitas Andalas, Indonesia) } \\
\text { Lucky Zamzami } \\
\text { (Universitas Andalas, Indonesia) } \\
\text { Adri Febrianto } \\
\text { (Universitas Negeri Padang, Indonesia) } \\
\text { Ikhwan } \\
\text { Aisiah } \\
\text { (Universitas Negeri Padang, Indonesia) } \\
\text { (Universitas Negeri Padang, Indonesia) } \\
\text { Junaidi Indrawadi } \\
\text { (Universitas Negeri Padang, Indonesia) } \\
\text { Sadri Chaniago } \\
\text { (Universitas Andalas, Indonesia) }\end{array}$ & $\begin{array}{c}\text { Andreas Dego, Yoseph D.A. Santie, Sem Deehop, Ferdinand } \\
\text { Kerebungu } \\
\text { Analisis Kompetensi Pedagogik Guru IPS di SMP Negeri } 1 \text { Kabupaten } \\
\text { Pulau Morotai } \\
\text { Halaman } 81-89 \\
\text { Yuyut Chandra, Aidinil Zetra, Ria Ariyany } \\
\text { LKAAM Kota Solok) } \\
\text { Halaman 90-102 } \\
\text { Demokrasi Deliberatif Masyarakat Minangkabau (Studi Kasus: } \\
\text { Ike Sylvia, Syafri Anwar, Khairani } \\
\text { Pengembangan Instrumen Penilaian Autentik Berbasis Pendekatan } \\
\text { Authentic Inquiry Learning Pada Mata Pelajaran Sosiologi di Sekolah } \\
\text { Menengah Atas } \\
\text { Halaman 103-120 } \\
\text { Pawennari Hijjang, Lia Amelia } \\
\text { Assajingeng: Politik Kekerabatan di Pilkada Kabupaten Bone (Analisis } \\
\text { Antropologi Politik) } \\
\text { Halaman 121-134 }\end{array}$ \\
\hline $\begin{array}{c}\text { Layout Editor : } \\
\text { Rhavy Ferdyan, S.Pd. } \\
\text { Technical Support: } \\
\text { Rudi Mahesa, A.Md. } \\
\text { Alamat Redaksi: } \\
\text { Jurusan Sosiologi FIS UNP } \\
\text { Jl. Prof.Dr.Hamka } \\
\text { Kampus UNP Air Tawar } \\
\text { e-mail: sosan@ fis.unp.ac.id } \\
\text { Penerbit } \\
\text { Labor Jurusan Sosiologi } \\
\text { Universitas Negeri Padang }\end{array}$ & \\
\hline
\end{tabular}




\title{
Relevansi Kurikulum 2013 dengan Kebutuhan Peserta Didik di Era Revolusi 4.0
}

\author{
Reno Fernandes \\ Universitas Negeri Padang \\ Email: renofernandes@ fis.unp.ac.id
}

\begin{abstract}
Abstrak
Revolusi industri 4.0 yang didahului dengan perkembangan teknologi informasi mendatangkan generasi dengan karakter baru, yakni mereka yang disebut sebagai generasi digital native. Kehadiran generasi baru ini memberikan pengaruh yang signifikan pada semua lini kehidupan termasuk institusi pendidikan. Menghadapi perubahan tersebut pemerintah Republik Indonesia periode 2014-2019 melakukan revisi kurikulum 2013 dengan program intinya pembelajaran abad 21. Tidak lama kurikulum 2013 revisi diterapkan, pada periode kepemimpinan Presiden Joko Widodo 2019-2014, presiden kembali mengeluarkan instruksi kepada Mentri Pendidikan dan Kebudayaan untuk melakukan perombakan besar-besaran kurikulum pendidikan di Indonesia. Kondisi seperti pemaparan di atas merupakan sesuatu yang tidak baik terhadap pendidikan. Mengingat kurikulum merupakan pedoman dalam menjalankan pendidikan sehingga proses perubahan kurikulum tersebut harus berdasarkan kajian yang mendalam dan kurikulum harus dijalankan secara terencana dan berkelanjutan. Melalui artikel ini penulis akan memberikan kajian ilmiah mengenai alasan pentingnya melanjutkan penerapan kurikulum 2013 dengan memaparkan data dan fakta penerapan kurikulum 2013 selama ini. Artikel ini hadir melalui penelitian dengan menggunakan pendekatan kualitatif tipe studi pustaka (library research).
\end{abstract}

Kata kunci: Digital Native, Kurikulum, Peserta Didik, Revolusi Industri 4.0

\begin{abstract}
The industrial revolution 4.0, which was preceded by the development of information technology, brought a generation with new characters, as known as digitally native generations. The presence of this new generation has a significant influence on all lines of life, including educational institutions. Facing these changes, the government of the Republic of Indonesia in the period of 2014-2019 revised the 2013 curriculum with its core program of learning in the 21st century. Not long before the 2013 revised curriculum was implemented, during the presidential leadership period of Joko Widodo 20192014, the President again issued instructions to the Minister of Education and Culture to undertake a significant overhaul education curriculum in Indonesia. Conditions like the explanation above are something that is not good for education. Given the curriculum is a guideline in carrying out education so the curriculum change process must base on in-depth studies, and the curriculum must be a plan and sustainable manner. Through this article, the author will provide a scientific study of the importance of continuing the implementation of the 2013 curriculum by describing data and facts about the implementation of the 2013 curriculum. This article presents thorough research using a qualitative approach to the type of library research.
\end{abstract}

Keywords: Curriculum, Digital Native, Industrial Revolution 4.0, Students

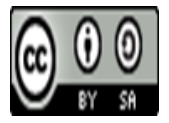

Received: November 21, 2019

Revised: December 27, 2019

Available Online: December 31, 2019 


\section{Pendahuluan}

Kebudayaan dalam suatu masyarakat turut memberikan pengaruh yang sangat tinggi dalam pengorganisasian kurikulum. Kebudayaan tersebut akan terlihat pada komponen kurikulum yang terdiri dari tujuan, kandungan (content), aktifitas pembelajaran (learning activities) dan evaluasi. Kebudayaan dapat menentukan perkembangan kepribadian setiap anggota masyarakat dengan menciptakan tolak ukur tipe kepribadian yang ideal sehingga menghasilkan individu yang secara teoritis merefleksikan konfigurasi nilai, karakteristik, sikap dan perilaku yang secara budaya sempurna (Zais, 1976).

Perkembangan teknologi informasi seringkali diasumsikan membawa dampak terbentuknya kebudayaan baru seperti nilai-nilai dan masyarakat dengan kepribadian baru. Manusia yang lahir dari perkembangan teknologi informasi adalah Generasi $Z$ dan $\alpha$ atau biasa disebut dengan digital native. Pakar pendidikan Mark Prensky dalam (Mardina, 2011) mengemukakan digital natives adalah generasi yang sudah terkondisikan dengan lingkungan teknologi digital sebagai bagian yang tidak terpisahkan dari kehidupannya. Menurut (Li, Leung, \& Tam, 2007) Karakteristik digital native sebagai orang yang 'opportunistic' dan 'omnivorous' yang menikmati sesuatu dalam lingkungan yang serba online (ingin mendapatkan informasi dengan cepat); menyukai kolaborasi dari satu orang ke orang lain (secara berjejaring); multitasking; menyukai proses kerja secara paralel; menyukai sesuatu yang berbentuk gambar interaktif dibanding dengan teks; menyukai bekerja sebagai suatu 'games'; mengharapkan suatu penghargaan, puas dengan sesuatu yang serba instan; akses secara random (hypertext). Senada dengan pendapat di atas (Ghaith, 2010) juga mengemukakan hal yang sama sehingga diasumsikan bahwa gaya belajar digital native sudah terbiasa dengan serba cepat, menciptakan koneksi secara acak, memproses informasi visual secara dinamis dan bisa saja informasi yang diperoleh bisa akurat atau bermanfaat.

Karakteristik generasi digital natives seperti ungkapan di atas dianggap sebagai tantangan sekaligus peluang bagi perkembangan pendidikan di Indonesia. Penelitian tentang keberadaan digital native dalam pendidikan dan pembelajaran di Indonesia telah banyak dikaji seperti yang dilakukan oleh (Juliane, Arman, \& Supriana, 2017), (Vivianti, 2017), (Mardianto, 2019) mengungkapkan hal yang relatif sama yaitu bahwa hadirnya teknologi informasi membawa dampak hadirnya generasi baru yaitu digital native. Keberadaan digital native diasumsikan sebagai tantangan dalam institusi pendidikan karena kehadiran teknologi digital saat ini membawa kesenjangan pengetahuan dan karakter antara guru sebagai digital immigrants dengan siswa sebagai digital natives. Sebagai upaya meminimalisir kesenjangan tersebut pendidik dituntut untuk cakap menggunakan teknologi sebagai sarana belajar mengajar.

Dalam institusi pendidikan di Indonesia, kurikulum yang diterapkan pada pendidikan dasar dan menengah adalah kurikulum 2013. Sebagaimana yang digaungkan kurikulum 2013 saat ini menggunakan framework pembelajaran abad ke-21 yaitu kurikulum yang menekankan pada keterampilan 4C diantaranya critical-thinking and problem-solving skills, (communication and collaboration skills, (c) creativity and innovation skills). Selain itu pada kurikulum 2013 juga dikembangkan literasi teknologi informasi dan komunikasi, serta penguatan pendidikan karakter pada pengembangan karakter (character building) dan nilai spiritual (spiritual value). Keselurah standar pendidikan di Indonesia ini dirumuskan menjadi Indonesian Partnership for 21 Century Skill Standard (Puspito, 2017).

Pada tatanan implementasinya sebenarnya kurikulum 2013 telah diluncurkan pada awal tahun 2014 pada masa Menteri Pendidikan dan Kebudayaan Muhammad Nuh di era Presiden Susilo Bambang Yudhoyono, namun pada tahun yang sama dengan pemerintahan yang

Jurnal Socius: Journal of Sociology Research and Education Vol. 6, No.2, Th. 2019 
berbeda yaitu Presiden Joko Widodo dilakukan evaluasi dan perbaikan hingga tahun 2017. Kurikulum 2013 pasca revisi 2017 baru ditetapkan untuk diterapkan pada seluruh sekolah di Indonesia direncanakan selesai pada tahun ajaran 2019-2020 (Kemendikbud RI, 2014).

Belum selesai diterapkan seluruh Indonesia, wacana yang dibangun pasca pelantikan menteri pendidikan di era kepemimpinan periode baru 2019-2024 Presiden Joko Widodo adalah perubahan kurikulum dalam institusi pendidikan Indonesia. Diketahui dalam siaran persnya Presiden Joko Widodo mengintruksikan Nadiem Makarim sebagai Menteri Pendidikan yang baru diharapkan dapat merubah kurikulum pendidikan di Indonesia berorientasi kepada perkembangan masyarakat digital yaitu adaptif terhadap revolusi industri 4.0. Salah satu perubahan mendasar dalam kurikulum seperti yang diwacanakan oleh presiden adalah kurikulum pendidikan menengah yang mengedepankan pengembangan softskill siswa (Tempo, 2019)

Berdasarkan pemaparan latar belakang di atas artikel ini akan menjawab bagaimana relevansi kurikulum 2013 dengan era evolusi 4.0 dan bagaimana penerapan kurikulum 2013 pasca revisi di Indonesia. Artikel ini secara tidak langsung ingin menyatakan sikap bahwa wacana pergantian kurikulum 2013 pada pendidikan dasar dan menengah untuk saat ini belum tepat dilakukan. Sikap tersebut akan dibuktikan secara ilmiah dengan kajian teori - teori pendidikan dan perkembangan peserta didik.

\section{Metode Penelitian}

Artikel ini merupakan hasil studi dokumen dan kajian kepustakaan (library research). Data, informasi dan gagasan-gagasan konseptual dihimpun dari dokumen kurikulum 2013 dan berbagai literatur, seperti: artikel/ jurnal ilmiah, buku, laporan penelitian, dan berbagai media relevan. Penelitian ini analisis isi kurikulum melalui teknik content analytic guna memahami tujuan dan manfaat kurikulum secara lebih dalam. Singkatnya, analisis penelitian ini mengadopsi pendekatan kualitatif, dan hasilnya disajikan secara deskriptif-analitis.

\section{Hasil dan Pembahasan}

\section{Hasil Penelitian}

\section{Kebudayaan, Sekolah, dan Kurikulum}

Pada masa masyarakat praliterasi pendidikan berisi mengenai nilai budaya yang ada di tengah masyarakat. Pendidikan diajarkan oleh orang dewasa secara sederhana atau berdasarkan pengalaman orang tua hidup dalam lingkup kebudayaan masyarakatnya. Hal ini disebabkan orang tua masih menguasai hampir semua muatan budaya yang perlu di transfer kepada generasi berikutnya agar anak bisa memenenuhi kebutuhan hidupnya (Ansyar, 2015).

Kondisi berbeda terjadi di zaman modern, pendidikan tidak bisa hadir sebagai media untuk sekedar memelihara dan pewaris kebudayaan, namun kehadiran sekolah harus memiliki nilai lebih yaitu mampu mengembangkan kebudayaan itu sendiri. Modernisasi yang diiringi dengan perkembangan teknologi dan informasi membawa dampak percepatan pengetahuan, keterampilan, dan sikap yang harus dikuasai setiap anak agar dapat sukses hidup ditengah masyarakat modern. Kompleksitas inilah yang membuat peranan orang tua tidak dapat dominan lagi menjadi pendidik anak sendiri seperti masa dahulu.

Salah satu perdebatan itu terkait fungsi pokok sekolah yang berakibat pada orientasi kurikulum. Seperti telah disinggung di atas, ada yang menginginkan sekolah sebagai pemelihara dan penerus kebudayaan, dan ada yang menginginkan sekolah sebagai sarana pengembangan individu anak yang mungkin tidak serasi dengan kebudayaan masyarakatnya. 
Menurut pandangan terakhir, sekolah harus lebih berperan sebagai pembawa perubahan (agent of change) untuk menghasilkan rekonstruksi sosial, berbeda dengan pendapat yang terdahulu yang ingin sekolah sebagai pemelihara status quo kebudayaan.

Apakah sekolah berfungsi untuk memanusiakan manusia, merekonstruksi kehidupan sosial warga atau mengoptimalkan pengembangan potensi anak, yang jelas adalah kurikulum sekolah harus mengakomodasi banyak kepentingan politik, aspirasi berbagai golongan dan etnik, serta keinginan berbagai stakeholders pendidikan lain, seperti orang tua (masyarakat), Siswa dan misi pendidikan negara bagi kemajuan kehidupan nasional dan pengembangan karakter bangsa (nation building).

Agar dapat mengakomodasi berbagai harapan dan aspirasi tersebut, kurikulunm sekolah harus disusun sinkron dengan potensi anak sebagai subjek pendidikan agar mereka menjadi orang yang diinginkan (desirable persons). Artinya, kurikulum perlu disusun sedemikian rupa agar serasi dengan harapan dan aspirasi stakeholders pendidikan dan sejalan dengan kebudayaan dan perkembangan masyarakat, selain bagi pemenuhan kebutuhan realisasi diri (self-realization) siswa. Hal ini mengindikasikan bahwa kurikulum yang dilaksanakan dengan metode didaktik melalui ekspose verbal, ceramah atau kuliah saja, dan yang keberhasilannya didasarkan pada hasil ujian tertulis semata, cenderung kurang memadai, jika harapan terhadap pendidikan ialah untuk membekali siswa dengan kompetensi kecakapan hidup. Kompetensi kecakapan hidup itu bukan hanya sekadar menyerah konten kurikulum saja, tetapi jauh lebih luas dari itu, yaitu supaya siswa mampu melakukan rekonstruksi sosial dengan bekal kemampuan seperti generasi pengetahuan (knowledge generation), rekonstruksi pengetahuan (knowledge reconstruction), dan aplikasi pengetahuan (knowledge application) untuk mengantar siswa menuju aktualisasi diri (self-actualization) dalam konteks kehidupan masa depan dan dunia yang cepat berubah (a rapid changing society).

Dalam melakukan perancangan, kurikulum pengambilan keputusan perlu memperhatikan beberapa hal diantaranya: 1) di era perubahan sosial budaya yang cepat, pendidikan di sekolah bisa berfungsi sebagai vehicle for change (kendaraan perubahan), recreating reality (penciptaan kembali realita) seperti pengajaran moral, akhlak mulia, multikulturisme, persamaan hak, keadilan sosial, pendidikan lingkungan hidup dan hak asasi manusia (Print, 1993); 2). Menurut Hilda Taba dalam (Plate, 2012) Perhatian pentingnya peningkatan pengembangan kecerdasan jamak (multiple intelligences development), seperti kematangan sosial, intelektual, dan emosional anak perkembangan kebutuhan personal siswa, seperti bakat, minat, dan kemampuan lain yang berbeda pada diri tiap anak dalam konteks yang memungkinkan individu hidup serasi dalam keberagaman kelompok sosial sendiri dan kelompok sosial lain (Tyler, 2013).

Pengambil keputusan pendidikan harus profesional, yaitu orang yang memahami pengaruh sosial-kemasyarakatan, psikologi perkembangan, teori belajar, filsafat pendidikan, hasil penelitian pendidikan dan berbagai variabel lainnya yang berpengaruh pada efektivitas dan efisiensi kurikulum dan pembelajaran. Hal ini juga ditegaskan (Parkay, Anctil, \& Glen J. Hass, 2010) bahwa pengembang kurikulum bukan saja harus menguasai teori, prinsip dan hasil penelitian pendidikan, tetapi harus pula mampu mengaplikasikan pengetahuan, metode, dan keterampilan yang telah dikembangkan pakar, peneliti, dan praktisi kurikulum.

\section{Perubahan Sosial dan Karakter Peserta Didik di Era Revolusi 4.0}

Era perkembangan teknologi informasi memengaruhi aktivitas sekolah dengan sangat masif. Informasi dan pengetahuan baru menyebar dengan mudah dan aksesibel bagi siapa saja yang membutuhkannya. Pendidikan mengalami disrupsi yang sangat hebat sekali. Peran guru

Jurnal Socius: Journal of Sociology Research and Education Vol. 6, No.2, Th. 2019 
yang selama ini sebagai satu-satunya penyedia ilmu pengetahuan sedikit banyak bergeser menjauh darinya. Di masa mendatang, peran dan kehadiran guru di ruang kelas akan semakin menantang dan membutuhkan kreativitas yang sangat tinggi.

Abad ke-21 ditandai dengan era revolusi industri 4.0 sebagai abad keterbukaan atau abad globalisasi, artinya kehidupan manusia pada abad ke-21 mengalami perubahan-perubahan yang fundamental yang berbeda dengan tata kehidupan dalam abad sebelumnya. Dikatakan abad ke21 adalah abad yang meminta kualitas dalam segala usaha dan hasil kerja manusia. Dengan sendirinya abad ke-21 meminta sumberdaya manusia yang berkualitas, yang dihasilkan oleh lembaga-lembaga yang dikelola secara profesional sehingga membuahkan hasil unggulan. Tuntutan-tuntutan yang serba baru tersebut meminta berbagai terobosan dalam berfikir, penyusunan konsep, dan tindakan-tindakan. Dengan kata lain diperlukan suatu paradigma baru dalam menghadapi tantangan-tantangan yang baru, demikian kata filsuf Khun. Menurut filsuf Khun apabila tantangan-tantangan baru tersebut dihadapi dengan menggunakan paradigm lama, maka segala usaha akan menemui kegagalan. Tantangan yang baru menuntut proses terobosan pemikiran (breakthrough thinking process) apabila yang diinginkan adalah output yang bermutu yang dapat bersaing dengan hasil karya dalam dunia yang serba terbuka (Tilaar, 1998).

Dalam konteks pembelajaran abad 21, pembelajaran yang menerapkan kreativitas, berpikir kritis, kerjasama, keterampilan komunikasi, kemasyarakatan dan keterampilan karakter, tetap harus dipertahankan bahwa sebagai lembaga pendidikan peserta didik tetap memerlukan kemampuan teknik. Pemanfaatan berbagai aktifitas pembelajaran yang mendukung. merupakan keharusan dengan model resource sharing dengan siapapun dan dimanapun, pembelajaran kelas dan lab dengan augmented dengan bahan virtual, bersifat interaktif, menantang, serta pembelajaran yang kaya isi bukan sekedar lengkap.

Dunia pendidikan pada era revolusi industri 4.0 berada di masa pengetahuan (knowledge age) dengan percepatan peningkatan pengetahuan yang luar biasa. Percepatan peningkatan pengetahuan ini didukung oleh penerapan media dan teknologi digital yang disebut dengan information super highway (Gates, 1996). Gaya kegiatan pembelajaran pada masa pengetahuan (knowledge age) harus disesuaikan dengan kebutuhan pada masa pengetahuan (knowledge age). Bahan pembelajaran harus memberikan desain yang lebih otentik untuk melalui tantangan di mana peserta didik dapat berkolaborasi menciptakan solusi memecahkan masalah pelajaran. Pemecahan masalah mengarah ke pertanyaan dan mencari jawaban oleh peserta didik yang kemudian dapat dicari pemecahan permasalahan dalam konteks pembelajaran menggunakan sumber daya informasi yang tersedia.

\section{Kurikulum 2013 dan Pembelajaran Abad 21}

Di Indonesia lahirnya kurikulum 2013 revisi merupakan kurikulum terakhir setelah 10 kali mengalami perubahan kurikulum yang mendasar. Proses perubahan kurikulum tersebut pada satu sisi dapat dipahami sebagai suatu dinamika konstruktif mengingat setiap pakar pendidikan dan pengambil kebijakan memiliki pandangan yang beragam dalam memandang pendidikan. Selain itu perubahan kurikulum adalah sesuatu yang harus dilakukan secara berkelanjutan karena merupakan suatu konsekuensi logis atas tuntutan dan tantangan zaman.

Pada masyarakat modern yang dinamis dan sarat teknologi dan pengetahuan, penetapan prioritas tujuan pendidikan dan penyusunan kurikulum cenderung mengalami banyak perdebatan, mengingat saratnya muatan pengetahuan yang harus masuk kurikulum dan bervariasinya kepentingan dan aspirasi berbagai stakeholders pendidikan. Karena itu, bukan hal yang mudah untuk menyamakan persepsi tentang mata pelajaran dan organisasi materi

Jurnal Socius: Journal of Sociology Research and Education Vol. 6, No.2, Th. 2019 
pelajaran dalam kurikulum. Dengan kata lain, melimpahnya volume pengetahuan, bervariasinya filsafat pendidikan dan beragamnya teori belajar dan pengembang kurikulum, maka seleksi materi ajar, pemilihan kegiatan belajar dan penetapan pengalaman belajar, serta sistem evaluasi kurikulum dan pembelajaran, akan melalui suatu proses perdebatan yang tidak mudah (Ansyar, 2015).

Dapat dijelaskan kurikulum 2013 berakar dari landasan filosofi bangsa Indonesia, landasan sosiologis, psikopedagogis, teoritis dimana dapat dirangkum dalam tujuan kurikulum 2013 yaitu untuk mempersiapkan manusia Indonesia agar memiliki kemampuan hidup sebagai pribadi dan warga negara yang beriman, produktif, kreatif, inovatif, dan afektif serta mampu berkontribusi pada kehidupan bermasyarakat, berbangsa, bernegara,dan peradaban dunia.

Kemendikbud melalui kurikulum 2013 revisi merumuskan pembelajaran abad 21 sebagai paradigma baru dalam institusi pendidikan yang menekankan pada kemampuan peserta didik dalam mencari tahu dari berbagai sumber, merumuskan permasalahan, berpikir analitis dan kerjasama serta berkolaborasi dalam menyelesaikan masalah (Litbang Kemdikbud, 2013). Adapun penjelasan mengenai framework pembelajaran abad ke-21 menurut (BSNP:2010) dirumuskan dalam keterampilan 4C diantaranya critical-thinking and problem-solving skills, (communication and collaboration skills, (c) creativity and innovation skills). Selain itu pada kurikulum 2013 juga dikembangkan literasi teknologi informasi dan komunikasi, serta penguatan pendidikan karakter pada pengembangan karakter (character building) dan nilai spiritual (spiritual value). Keselurah standar pendidikan di Indonesia ini dirumuskan menjadi Indonesian Partnership for 21 Century Skill Standard (IP-21CSS).

Tabel 1. Indonesian Partnership for 21 Century Skill Standard (IP-21CSS)

\begin{tabular}{|c|c|c|}
\hline $\begin{array}{c}\text { Framework } 21^{\text {st }} \text { Century } \\
\text { Skill }\end{array}$ & IP-21CSS & Aspek \\
\hline $\begin{array}{l}\text { Creativity Thinking and } \\
\text { Innovation }\end{array}$ & $4 C s$ & $\begin{array}{ll}\text { - } & \text { Berpikir Secara Kreatif } \\
\text { - } & \text { Bekerja dengan lainnya } \\
\text { - } & \text { Mengimplementasikan inovasi } \\
\end{array}$ \\
\hline $\begin{array}{l}\text { Critical Thinking and } \\
\text { Problem Solving }\end{array}$ & & $\begin{array}{l}\text { - Penalaran Efektif } \\
\text { - Menggunakan system berfikir } \\
\text { - Membuat penilaian dan keputusan } \\
\text { - Memecahkan masalah } \\
\end{array}$ \\
\hline $\begin{array}{l}\text { Communication and } \\
\text { Collaboration }\end{array}$ & & $\begin{array}{l}\text { - Berkomunikasi secara jelas } \\
\text { - Berkolaborasi dengan orang lain }\end{array}$ \\
\hline $\begin{array}{l}\text { Information, Media and } \\
\text { Technology Skills }\end{array}$ & ICTs & $\begin{array}{l}\text { - Mengakses dan mengevaluasi } \\
\text { informasi } \\
\text { - Menggunakan dan menata informasi } \\
\text { - Menganalisis dan menghasilkan media } \\
\text { - Mengaplikasikan teknologi secara } \\
\text { efektif }\end{array}$ \\
\hline Life and Career Skills & $\begin{array}{l}\text { Character } \\
\text { Building }\end{array}$ & $\begin{array}{l}\text { - Menunjukkan perilaku scientific } \\
\text { attitude (Hasrat ingin tahu, jujur, teliti, } \\
\text { terbuka, dan penuh kehati-hatian) } \\
\text { - Menunjukkan penerimaan nilai moral } \\
\text { yang berlaku di masyarakat }\end{array}$ \\
\hline
\end{tabular}




\begin{tabular}{lrr} 
Spiritual values & - $\begin{array}{l}\text { Menghayati konsep ke-Tuhanan } \\
\text { melalui ilmu pengetahuan }\end{array}$ \\
& - $\begin{array}{l}\text { Meninternalisasikan } \\
\text { spiritual dalam kehiduapn sehari-hari }\end{array}$ \\
\hline
\end{tabular}

\section{Implementasi Kurikulum 2013}

Kurikulum 2013 merupakan kurikulum yang paling unik diterapkan di Indonesia. Dalam perkembangannya kurikulum ini telah menjadi kebijakan dan diterapkan pada tahun ajaran 2013/2014 bertepatan dengan akhir masa jabatan Muhammad Nuh sebagai menteri pendidikan dan kebudayaan pada era Presiden Susilo Bambang Yudhoyono. Tidak lama kemudian setelah pelantikan menteri pendidikan baru Anis Baswedan dimasa kepemimpinan Presiden Joko Widodo pemberlakuan kurikulum 2013 harus dihentikan pelaksanaannya pada sebahagian sekolah di Indonesia. Dengan alasan penerapan kurikulum 2013 pada era ini hanya pada sekolah percontohan dan akan diterapkan secara serentak pada tahun 2019/2020 setelah dilakukan revisi. Diketahui proses revisi kurikulum 2013 dimasa Anis Baswedan selesai tahun 2016 seiring dengan dikeluarkan Permendikbud Nomor 20 - 24 tentang standar kompetensi lulusan, standar isi, standar proses, kompetensi dasar dan standar penilaian.

Pelaksanaan pendidikan di Indonesia mulai dari tahun 2014 sampai tahun ajaran ini dapat dikatakan belum memiliki panduan yang terstandarisasi dimana masih terdapat sekolah yang memberlakukan Kurikulum Tingkat Satuan Pendidikan (KTSP) dan belum menerapkan kurikulum 2013. Tercatat menurut hingga tahun 2018 menurut Direktur Jenderal Guru dan Tenaga Kependidikan Kemendikbud, Hamid Muhammad mengatakan, saat ini terdapat sekitar 78.000 sekolah yang memasuki tahap akhir implementasi kurikulum 2013 (Budi, 2018). Kenyataan ini memperlihatkan bahwa ada 2 standar kurikulum pendidikan di Indonesia sejak tahun 2014 -2019 ini yaitu KTSP dan Kurikulum 2013.

Dalam berbagai penelitian tentang implementasi kurikulum 2013 ditemukan sebahagian besar guru tidak mengerti menerapkan kurikulum 2013 hal ini terungkap dari analisis content terhadap 174 judul skripsi pada topik kependidikan dan pengajaran di Jurusan Sosiologi dari tahun 2014-2019 didapatkan data, meskipun kurikulum 2013 telah diterapkan pada sekolah yang diteliti, namun pendekatan yang digunakan guru sosiologi mengajar tetap saja teacher centered learning dengan menggunakan metode ceramah. Sementara dalam standar proses kurikulum 2013 dinyatakan bahwa pendekatan yang digunakan oleh guru dalam mengajar harus student centered learning dengan menggunakan model-model pembelajaran yang menunjang keaktifan siswa. Fenomena ini tidak hanya terjadi pada guru matapelajaran sosiologi pada guru mata pelajaran lain juga terjadi seperti penelitian (Hutagalung \& Simarmata, 2015) dari observasi yang dilakukannya pada pembelajaran yang dilakukan guru fisika di SMP Negeri Siso, terlihat guru dalam mengajar masih menggunakan cara konvensional dalam mengajar yaitu dengan ceramah. Begitu juga dengan penelitian (Halim, Didimus Tanah Boleng, \& Labulan, 2019) dan (Eka Trisianawati, 2016) semua penelitian tersebut menyatakan guru masih saja mengajar menggunakan metode ceramah dalam mengajar.

\section{Pembahasan}

\section{Landasan Pengembangan Kurikulum 2013}

Pertanyaan yang harus dijawab dalam artikel ini adalah apakah kurikulum 2013 harus diganti? Lalu bagaimana implementasi kurikulum 2013 di Indonesia. Jawaban atas pertanyaan tersebut akan dijawab dengan kerangka kesesuaian kurikulum 2013 dengan landasan 
pengembangan kurikulum yaitu landasan filosofis, landasan sosiologis, landasan psikologis dan teori belajar.

\section{Landasan Filosofis}

Filsafat adalah sesuatu yang harus dijadikan pedoman dalam penyusunan kurikulum. Menurut (Ornstein \& Hunkins, 2016) tanpa filsafat pendidikan kehilangan pedoman ketika merancang, melaksanakan dan meningkatkan kualitas pendidikan. Pentingnya keberadaan filsafat dalam kurikulum juga dinyatakan oleh (Zais, 1976) menurutnya, filsafat mengkaji knowledge of the good life yang dapat membantu peserta didik memahami hakikat hidup yang baik bagi individu dan masyarakat.

Kurikulum 2013 dirancang tidak terlepas dari landasan filsafat agar penyelenggaraan pendidikan dapat memberikan dasar bagi pengembangan seluruh potensi peserta didik menjadi manusia Indonesia berkualitas yang tercantum dalam tujuan pendidikan nasional. Kurikulum 2013 dikembangkan menggunakan filosofi sebagai berikut: (1) Pendidikan berakar pada budaya bangsa untuk membangun kehidupan bangsa masa kini dan masa mendatang, (2) Peserta didik adalah pewaris budaya bangsa yang kreatif, (3) Pendidikan ditujukan untuk mengembangkan kecerdasan intelektual dan kecemerlangan akademik melalui pendidikan disiplin ilmu, dan (4) Pendidikan untuk membangun kehidupan masa kini dan masa depan yang lebih baik dari masa lalu dengan berbagai kemampuan intelektual, kemampuan berkomunikasi, sikap sosial, kepedulian, dan berpartisipasi untuk membangun kehidupan masyarakat dan bangsa yang lebih baik (experimentalism and social reconstructivism).

Dengan filosofi sebagaimana di atas pendidikan dapat mengembangkan kehidupan individu peserta didik dalam beragama, seni, kreativitas, berkomunikasi, nilai dan berbagai dimensi inteligensi yang sesuai dengan diri seorang peserta didik dan diperlukan masyarakat, bangsa dan umat manusia (Kemendikbud RI, 2018).

\section{Landasan Sosiologis}

Kurikulum sekolah terbentuk dari nilai- nilai sosial masyarakat dan yang terpenting adalah cerminan dari nilai- nilai tersebut dalam kepribadian siswa. Perbedaan konteks sosial merekonstruksi dimensi nilai- nilai dari kurikulum. Nilai- nilai pendidikan dalam berbagai masyarakat mencerminkan konteks historikal, kultural dan politik.Seperti nilai nilai pendidikan yang dapat kita lihat pada berbagai negara berbeda, yaitu, toleransi, kepercayaan, saling menghormati, keberanian dan kejujuran, kehormatan dan kebaikan, keadilan, integritas, kerja sama, identitas nasional, misi keagamaan dan lainnya. Semua ini bukan berarti dapat diaplikasikan pada negara yang berbeda faham ataupun bentuk pemerintahan. Poin utama mengenai nilai- nilai ini adalah bahwa nilai pendidikan yang disusun bersama dengan kurikulum sekolah senantiasa mencerminkan dimensi dominan dalam masyarakat, baik religiusitas, fundamentalitas maupun demokratis.

Kurikulum 2013 dikembangkan atas dasar adanya kebutuhan akan perubahan rancangan dan proses pendidikan dalam rangka memenuhi dinamika kehidupan masyarakat, bangsa, dan negara, sebagaimana termaktub dalam tujuan pendidikan nasional. Dewasa ini perkembangan pendidikan di Indonesia tidak bisa dilepaskan dari perkembangan ilmu pengetahuan, teknologi, dan seni. Perubahan ini dimungkinkan karena berkembangnya tuntutan baru dalam masyarakat, dunia kerja, dan dunia ilmu pengetahuan yang berimplikasi pada tuntutan perubahan kurikulum secara terus menerus. Hal itu dimaksudkan agar pendidikan selalu dapat menjawab tuntutan perubahan sesuai dengan jamannya. Dengan demikian keluaran pendidikan akan mampu memberikan kontribusi secara optimal dalam upaya membangun masyarakat berbasis pengetahuan (knowledge-based society).

Jurnal Socius: Journal of Sociology Research and Education Vol. 6, No.2, Th. 2019 


\section{Landasan Psikologi}

Kurikulum 2013 dimaksudkan untuk memenuhi tuntutan perwujudan konsepsi pendidikan yang bertumbu pada perkembangan peserta didik beserta konteks kehidupannya sebagaimana dimaknai dalam konsepsi pedagogik transformatif. Konsepsi ini menuntut bahwa kurikulum harus didudukkan sebagai wahana pendewasaan peserta didik sesuai dengan perkembangan psikologisnya dan mendapatkan perlakuan pedagogis sesuai dengan konteks lingkungan dan jamannya.

Hadirnya Revolusi 4.0 pada abad 21 ini membawa arah baru pendidikan di Indonesia yaitu rumusan framework pembelajaran abad ke-21 yang disebut dengan Indonesian Partnership for 21 Century Skill Standard (IP-21CSS). Dalam framework tersebut dinyatakan bahwa penekanan pembelajaran harus pada pengembangan keterampilan 4C diantaranya critical-thinking and problem-solving skills, (communication and collaboration skills, (c) creativity and innovation skills). Selain itu pada kurikulum 2013 juga dikembangkan literasi teknologi informasi dan komunikasi, serta penguatan pendidikan karakter pada pengembangan karakter (character building) dan nilai spiritual (spiritual value).

\section{Landasan Teoritis}

Kurikulum 2013 dikembangkan atas teori "pendidikan berdasarkan standar" (standardbased education), dan teori kurikulum berbasis kompetensi (competency-based curriculum). Pendidikan berdasarkan standar menetapkan adanya standar nasional sebagai kualitas minimal warganegara yang dirinci menjadi standar isi, standar proses, standar kompetensi lulusan, standar pendidik dan tenaga kependidikan, standar sarana dan prasarana, standar pengelolaan, standar pembiayaan, dan standar penilaian pendidikan. Kurikulum berbasis kompetensi dirancang untuk memberikan pengalaman belajar seluas luasnya bagi peserta didik dalam mengembangkan kemampuan untuk bersikap, berpengetahuan, berketerampilan, dan bertindak. Kurikulum 2013 menganut: (1) pembelajaran yang dilakukan guru (taught curriculum) dalam bentuk proses yang dikembangkan berupa kegiatan pembelajaran di sekolah, kelas, dan masyarakat; dan (2) pengalaman belajar langsung peserta didik (learnedcurriculum) sesuai dengan latar belakang, karakteristik, dan kemampuan awal peserta didik. Pengalaman belajar langsung individual peserta didik menjadi hasil belajar bagi dirinya, sedangkan hasil belajar seluruh peserta didik menjadi hasil kurikulum.

\section{Relevansi Kurikulum 2013 dengan era Revolusi Industri 4.0}

Pengembangan kurikulum merupakan kegiatan yang kompleks yang memerlukan pertimbangan pengambilan keputusan strategis dan mendasar. Umpamanya, keputusan mengenai tujuan umum dan tujuan khusus yang harus direncanakan untuk dicapai sekolah perlu ditetapkan dan dicarikan cara-cara strategis untuk mencapainya. Keputusan mengenai mata pelajaran umum dan khusus serta materi pembelajaran atau konten kurikulum yang spesifik apa saja yang perlu dipilih untuk dimasukkan dalam kurikulum, perlu pula ditetapkan dengan cermat. Selain itu, keputusan tentang kegiatan belajar, pengalaman belajar yang menunjang pencapaian tujuan umum dan tujuan khusus sekolah harus dirancang dan dilaksanakan dengan baik melalui proses pembelajaran di sekolah.

Untuk mencapai tujuan pendidikan, kurikulum dan pembelajaran tidak boleh hanya fokus pada transfer konten atau materi kepada siswa, namun kurikulum harus dapat memfasilitasi siswa agar dia bisa menggenerasi atau mengkonstruksi konten kurikulum menjadi pengetahuan baru siswa. Maka sekolah di era modern perlu fokus pada optimalisasi pengembangan potensi 
tiap siswa adaptif terhadap perkembangan pengetahuan dan perubahan zaman. Artinya, untuk menghadapi kehidupan di era informasi, optimalisasi perkembangan potensi siswa harus merupakan agenda penting kurikulum sebagai bagian tak terpisahkan dari pendidikan itu sendiri di sekolah. Sebab, melalui potensi yang sudah berkembang, siswa bisa diberdayakan untuk membelajarkan dirinya masing-masing. Ini berarti pendidikan akan berlangsung jauh lebih efektif jika dibandingkan dengan pendidikan yang melalui pengajaran guru saja.

Dari gambaran landasan pengembangan pendidikan dapat disimpulkan bahwa kurikulum 2013 masih sangat relevan dapat dipakai pada pendidikan dasar dan menengah di Indonesia. Mengingat kurikulum 2013 pasca revisi baru diterapkan secara menyeluruh di Indonesia pada tahun ajaran 2019/2020 jadi sejatinya bagaimana pengaruh dan dampak kurikulum kepada peserta didik belum bisa mendapatkan hasil evaluasi secara valid.

Kurikulum 2013 sebagaimana yang dipaparkan pada hasil penelitian didapatkan bahwa dalam kurikulum tersebut Pembelajaran abad 21 yang menjadi Framework dalam kurikulum 2013 dirancang untuk beradaptasi dengan perkembangan teknologi informasi di era revolusi industri 4.0. Adaptasi yang dimaksud agar peserta didik mampu memanfaatkan sisi positif dari revolusi industri 4.0 dengan memiliki keterampilan 4C diantaranya critical-thinking and problem-solving skills, communication and collaboration skills, creativity and innovation Skills. Memiliki kemampuan Literasi teknologi informasi dan komunikasi. Pada sisi lain agar peserta didik tidak tercerabut dari kebudayaannya, pembelajaran Abad-21 juga memberikan arahan untuk penguatan pendidikan karakter melalui pengembangan karakter (character building) dan nilai spiritual (spiritual value). Jadi dapat dikatakan kurikulum 2013 masih sangat relevan dengan era Revolusi Industri 4.0.

\section{Kesimpulan}

Berdasarkan analisis terhadap konten dari kurikulum 2013 yang terdiri dari standar kompetesi lulusan, standar isi, standar proses, kompetensi dasar, standar penilaian, Permendikbud No 36 tahun 2013 dan Permendikbud no 160 tahun 2014 yang menjadi dasar penerapan kurikulum 2013 di Indonesia dapat disimpulkan bahwa kurikulum 2013 adalah kurikulum yang telah dibuat dengan perencanaan yang matang dan masih relevan menghadapi tantangan zaman dan sesuai dengan kebutuhan perkembangan peserta didik pada era Revolusi Industri 4.0. Dalam artikel penulis ingin menegaskan bahwa argumentasi untuk melakukan pergantian kurikulum belum cukup kuat karena secara logika evaluasi program pendidikan dimana sampai saat ini penilaian terhadap penerapan kurikulum 2013 belum bisa ditetapkan secara valid dan reliable karena kurikulum ini belum dilaksanakan secara menyeluruh di Indonesia pada tahun ajaran 2019/2020.

\section{Daftar Pustaka}

Ansyar, M. (2015). Kurikulum: Hakikat, Fondasi, Desain dan Pengembangan. Jakarta: Kencana.

Budi, K. (2018). Penerapan Kurikulum 2013, Sekolah Mesti Dukung Pengembangan Materi. Retrieved November 20, 2019, from Kompas.com website: https://edukasi.kompas.com/read/2018/06/30/22320611/penerapan-kurikulum-2013sekolah-mesti-dukung-pengembangan-materi?page=all

Eka Trisianawati, T. djudin dan R. setiawan. (2016). Pengaruh Model Pembelajaran Kooperatif Tipe Jigsaw Terhadap Hasil Belajar Siswa Pada Materi Vektor. Jurnal Pendidikan Fisika dan Aplikasinya (JPFA), 6(2), 51-60. 
Ghaith, G. (2010). An exploratory study of the achievement of the twenty-first century skills in higher education. Education and Training, 52(6), 489-498. https://doi.org/10.1108/00400911011068441

Halim, S., \& Labulan, P. (2019). Pengaruh Model Pembelajaran Discovery Learning dan Number Head Together Terhadap Aktivitas, Motivasi dan Hasil Belajar Siswa. Jurnal Pijar MIPA, 14(1), 55-61. https://doi.org/10.1017/CBO9781107415324.004

Hutagalung, A., \& Simarmata, U. (2015). Pengaruh Model Pembelajaran Kooperatif Tipe Group Investigation Terhadap Hasil Belajar Siswa. INPAFI (Inovasi Pembelajaran Fisika), 3(1), 284-291. https://doi.org/10.24114/inpafi.v3i1.8015

Juliane, C., Arman, A. A., \& Supriana, I. (2017). Digital Teaching Learning for Digital Native: Tantangan dan peluang. Jurnal Ilmiah Rekayasa dan Manajemen Sistem Informasi. 3(2), 29-35.

Kemendikbud RI. (2014). Permendikbud Nomor 160 Tahun 2014 Tentang Pemberlakuan Kurikulum 2006 dan Kurikulum 2014. Jakarta: Kemendikbud RI.

Kemendikbud RI. (2018). Permendikbud No 36 Tahun 2018. Jakarta: Kemendikbud RI.

Li, L. F., Leung, S., \& Tam, G. (2007). Promoting information literacy skills through webbased instruction: The Chinese University of Hong Kong Library experience. Library Management, 28(8-9), 531-539. https://doi.org/10.1108/01435120710837819

Mardianto. (2019). Peran Guru di Era Digital dalam Mengembangkan Self Regulated Learning Siswa Generasi Z untuk Pencapaian Hasil Pembelajaran Optimal. Seminar Nasional " Menjadi Siswa Yang Efektif Di Era Revolusi Industri 4.0, 150-157.

Mardina, R. (2011). Potensi Digital Natives Dalam Representasi Literasi Informasi Multimedia Berbasis Web Di Perguruan Tinggi. Jurnal Pustakawan Indonesia, 11(1).

Ornstein, A. C., \& Hunkins, F. P. (2016). Curriculum: Foundation, Principles and Issues. Boston: Pearson.

Parkay, F. W., Anctil, E. J., \& Glen J. Hass. (2010). Curriculum Leadership: Readings for Developing Quality Educational Programs. Boston: Pearson.

Plate, R. (2012). The Evolution of Curriculum Development in the Context of Increasing Social and Environmental Complexity. Creative Education, 3(8), 1311-1319. https://doi.org/10.4236/ce.2012.38192

Prensky, M. (2001). Digital Natives, Digital Immigrants. MCB University Press, 9(5).

Print, M. (1993). Curriculum Development and Disign. Cross Nest, NSW: Allen \& Unwin.

Puspito, D. W. (2017). Implementasi Literasi Digital Dalam Gerakan Literasi Sekolah. Konferensi Bahasa Dan Sastra (International Conference on Language, Literature, and Teaching) II.

Tempo. (2019). Jokowi Minta Nadiem Rombak Kurikulum Besar-Besaran. Retrieved from https://tekno.tempo.co/read/1266922/jokowi-minta-nadiem-rombak-kurikulum-besarbesaran

Tyler, R. W. (2013). Basic Principles of Curriculum and Instruction. In Basic Principles of Curriculum and Instruction. https://doi.org/10.7208/chicago/9780226820323.001.0001

Vivianti. (2017). Digital Teaching and Learning Bermuatan Pendidikan Karakter: Strategi Mengajar Untuk Digital. Prosiding "Profesionalisme Guru Abad XXI", Seminar Nasional IKA UNY Tahun 2018, 127-134.

Zais, R. S. (1976). Curriculum: Prinsiples and Foundation. New York: Harper \& Row Publishers. 